\title{
AUDIT KESELAMATAN JALAN UNTUK JALAN TOL YANG OPERASIONAL DI BAWAH 1 TAHUN
}

\section{Ni Luh Shinta Putu Eka Setyarini ${ }^{1}$, Aniek Prihatiningsih ${ }^{2}$, Liana Fentani Natalia Sianturi $^{3}$, Stephen Deprianto Gea ${ }^{4}$}

\author{
${ }^{1}$ Program Studi Sarjana Teknik Sipil, Universitas Tarumanagara \\ Email:niluhs@ft.untar.ac.id \\ ${ }^{2}$ Program Studi Sarjana Teknik Sipil, Universitas Tarumanagara \\ Email:aniekp@ft.untar.ac.id \\ ${ }^{3}$ Program Studi Sarjana Teknik Sipil, Universitas Tarumanagara \\ Email: liana.325150202@stu.untar.ac.id \\ ${ }^{4}$ Program Studi Sarjana Teknik Sipil, Universitas Tarumanagara \\ Email: stephen.325150152@stu.untar.ac.id
}

Masuk: 07-01-2021, revisi: 06-10-2021, diterima untuk diterbitkan: 27-10-2021

\begin{abstract}
ABSTRAK
Seiring dengan pertambahan jumlah penduduk maka jumlah kendaraanpun terus berkembang dari tahun ke tahun, sedangkan panjang ruas jalan tidak dapat menyusul secara signifikan, hal ini mengakibatkan terjadinya kemacetan lalu lintas. Upaya pemerintah mengurangi kemacetan dengan membangun jalan Tol yang diharapkan untuk mampu mengurangi kemacetan yang ada di jalan arteri. namun pada kenyataannya tidak mengurangi kemacetan bahkan jalan tol saat ini juga mengalami kemacetan. Beberapa jalan tol dibangun untuk mengurangi kemacetan yang ada di ruas jalan tol yang lama, karena apabila tidak dikurangi maka kemacetan menyebabkan stres dan lelah fisik, mengurangi produktifitas yang akhirnya mengakibatkan kecelakaan lalu lintas. Indonesia memiliki tingkat kematian yang jauh lebih tinggi dibandingkan dengan negara lainnya di ASEAN. Kecelakaan lalu lintas dipengaruhi tiga faktor utama yaitu faktor manusia, faktor kendaraan, dan faktor jalan. Dalam rangka upaya meningkatkan keselamatan jalan dan mengurangi angka kematian setiap tahunnya maka dilaksanakan observasi langung dengan mengunakan formulir Audit Keselamatan Jalan (AKJ) atau Road Safety Audit (RSA) pada ruas jalan tol operasional. Hasil dari observasi langung pada ruas jalan tol operasional di bawah 1 tahun secara umum masih terdapat banyak kekurangannya, seperti berbagai jenis kerusakan jalan terutama pada perkerasan, tidak adanya rambu peringatan tikungan ke kiri maupun ke kanan dan beberapa rambu lainnya, kecepatan eksisting yang lebih besar dari kecepatan rencana, dan median yang kurang baik karena tidak semua ruas terdapat pembatas
\end{abstract}

Kata Kunci: Kemacetan; Kecelakaan; Audit Keselamatan Jalan; Jalan Tol

\begin{abstract}
The imbalance population and number of vehicles increasing from year to year with number of roads causing traffic jam. Build toll road is the government's effort to solve traffic jam. The construction of toll roads that carried out by Government is expected to be able reduce traffic jam on arterial roads but in reality, does not reduce traffic jam even though traffic jam still exist on toll roads. Traffic jam causes stress and fatigue and can lead to traffic accidents. Indonesia has a much higher mortality rate compared to other countries. Traffic accidents are influenced by three main factors: human factors, vehicle factors, and road factors. To improve road safety and high number of deaths each year, it will be carried out research by direct observation using the Road Safety Audit (RSA) form of the Kunciran-Serpong Toll Road. The result of this research by direct observation on Kunciran-Serpong Toll Road in general there are still many shortcomings, such as various types of road damage and pavement, there are no signs to bend to the left or right, the drainage system is not good on several roads, and the median is not good because not all segments get fenced.
\end{abstract}

Keywords: Traffic Jam; Accident, Toll; Road Safety Audit 


\section{PENDAHULUAN}

\section{Latar Belakang}

Peningkatan jumlah penduduk dan pemanfaatan lahan yang tinggi seringkali menimbulkan kemacetan, bisa juga diakibatkan jumlah volume lalu lintas yang tinggi dan terus menerus atau through traffic (Mustikarani dan Suherdiyanto, 2016). Ketidakseimbangan jumlah kendaraan yang terus meningkat setiap tahun bila dibandingkan dengan panjang ruas jalan yang pertumbuhannya tetap, menyebabkan kemacetan lalu lintas. Pembangunan jalan tol merupakan salah satu upaya pemerintah dalam menangani kemacetan yang ada di ruas jalan non tol.

Jalan tol dapat diartikan sebagai jalan yang dibangun secara khusus untuk mempersingkat waktu tempuh dari satu tempat ke tempat lainnya dengan lalu lintas yang cukup padat (Setyarini, dkk, 2019). Dengan adanya jalan tol diharapkan untuk mampu mengurangi kemacetan yang terdapat di non tol, namun pada kenyataannya tidak mengurangi kemacetan bahkan jalan tol pun mengalami kemacetan. Kemacetan menyebabkan penurunan produktifitas kerja dari sektor kerja dan kehidupan, sehingga kemacetan menyebabkan emosi dan lelah fisik yang pada akhirnya mengakibatkan kecelakaan lalu lintas (Sediono dan Handoko, 2004). Menurut Global Status Report on Road Safety sebanyak 1,35 juta korban meninggal tiap tahun di seluruh dunia dan 2050 juta orang mengalami luka akibat kecelakaan lalu lintas (WHO, 2018). Kecelakaan lalu lintas menghilangkan lebih dari 1,2 juta jiwa setiap tahunnya yang berdampak besar pada kemajuan suatu negara karena menelan biaya 2,7\% dari PDB pemerintah di negara-negaraberpenghasilan tinggi dan 2,2\% PDB di negara-negara berpenghasilan rendah dan menengah (Wijnen \& Stipdonk, 2016).

Penulisan ini dibahas 2 jalan tol yang baru operasional di bawah 1 tahun yaitu: jalan tol KunciranSerpong dengan panjang 11,1 km dan Jalan Tol Layang Jakarta - Cikampek II, sepanjang $38 \mathrm{~km}$. Jalan tol Kunciran-Serpong diresmikan pada tanggal 06 Desember 2019, ruas ini termasuk dari tol lingkar luar Jakarta (JORR). Adanya tol Kunciran-Serpong menjadi jalur alternatif untuk masyarakat untuk menuju Tangerang-Merak atau Serpong-BSD. Dengan demikian akan mengurangi beban lalulintas yang masuk ke tol di dalam kota, sehingga terhindarnya kemacetan tol di dalam kota. Jalan tol Kunciran-Serpong memperlancar mobilitas komuter juga angkutan logistik dan memecah trafik dan arus barang dari Pelabuhan Merak ke Cikampek atau sebaliknya untuk masuk kembali ke jalan tol lingkar ini. Ruas jalan dan sistem pengoperasian jalan Tol Kunciran-Serpong dapat dilihat pada Gambar 1. Sebagai informasi, jalan Tol Kunciran-Serpong terdiri dari 2 seksi yaitu Kunciran-Parigi 6,72 km dan Parigi-Serpong 4,42 (Sumber: Badan Pengatur Jalan Tol, 2019). 


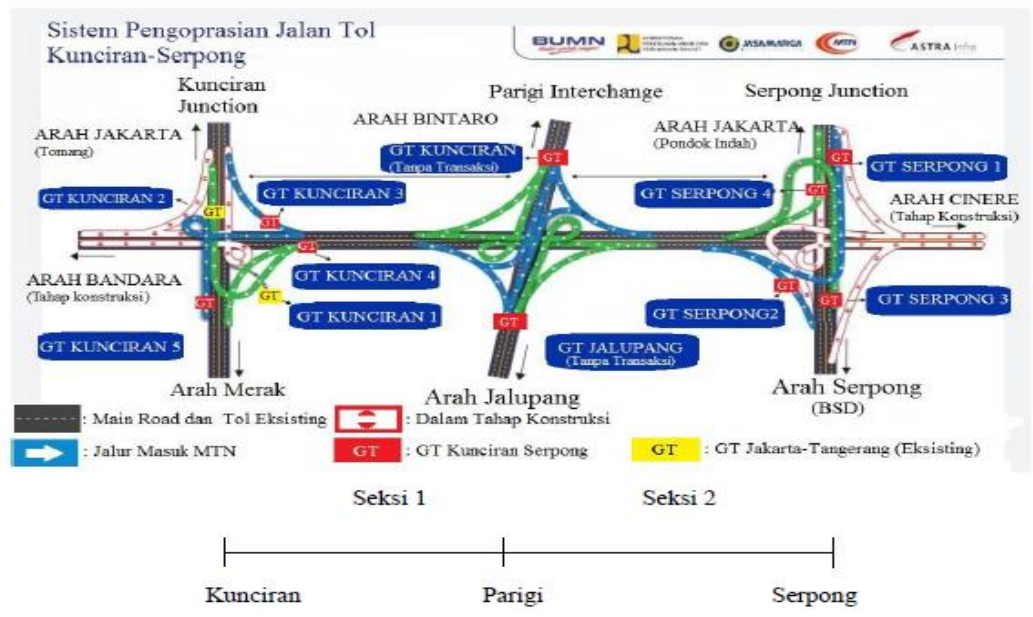

Gambar 1. Ruas jalan dan sistem pengoperasian pada Tol Kunciran-Serpong

Sumber Gambar: www.binamarga.com

Jalan tol Layang Jakarta-Cikampek II, dibangun sepanjang $38 \mathrm{~km}$ seusai pengukuran di lapangan yang membentang dari Cikunir sampai Karawang Barat dan terletak di tengah Jalan Tol JakartaCikampek melintasi Kota Bekasi, Kabupaten Bekasi dan Kabupaten Karawang Jawa Barat. Gambar dan pengoperasian jalan tol Layang laying Jakarta-Cikampek II dapat dilihat pada Gambar 2 di bawah. (Sumber: Badan Pengatur Jalan Tol, 2019)

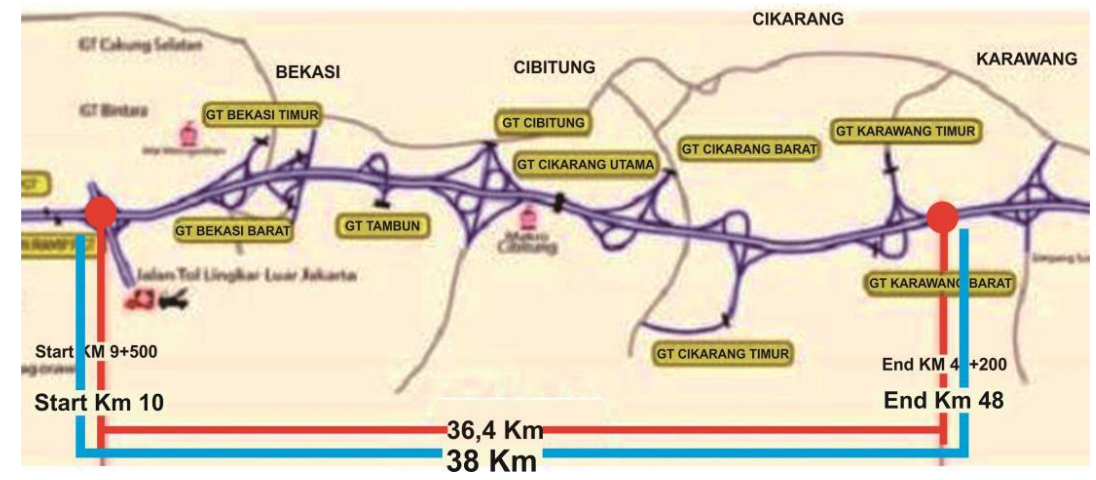

Gambar 2. Ruas Jalan Tol Layang Jakarta-Cikampek II

Sumber Gambar: www.jasamarga.com

\section{Rumusan Masalah}

Kecelakaan lalu lintas merupakan dampak negatif infrastruktur jalan dan berisiko terhadap keselamatan pengguna jalan, yang juga mengakibatkan kerusakan kendaraan dan barang sehingga menjadi kerugian materi (Zanuardi dan Suprayitno, 2018). Kecelakaan lalu lintas pada tahun 2012 sebanyak 109.038 dan jumlah korban meninggal dunia 25.131 orang (Puslitbang, 2013). Penyebab kecelakaan terbesar pertama adalah faktor manusia hampir $92 \%$, kedua faktor kendaraan sebesar $5 \%$ dan yang terakhir adalah faktor infrastruktur jalan dan lingkungan sebesar 3\% (Mulyono dkk, 2009b). Faktor manusia merupakan faktor paling dominan penyebab kecelakaan lalu lintas, seperti kurang antisipasi dan mengantuk, lalu faktor kendaraan seperti ban pecah, slip dan kerusakan mekanis akibat kelalaian dalam pemeliharaan (Setiawan dan Asima, 2019). 
Pembangunan dan penyelenggaraan jalan tol ternyata tidak bisa menjamin keselamatan dan kenyamanan pengguna jalan. Hal itu dibuktikan dengan data yang rilis oleh Badan Pusat Statistik Provinsi DKI Jakarta (2018) dimana Jumlah kecelakaan yang terjadi di Ruas Jalan Tol Jagorawi, Jakarta-Tangerang, Jakarta-Cikampek, Cawang-Tomang-Cengkareng sebanyak 862 kasus. Menurut Kapolri Jenderal Polisi Idham Azis (2019), jumlah kecelakaan lalu lintas tahun 2019 meningkat sebanyak 3\% dibanding tahun 2018 dimana tahun 2019 telah terjadi 107.500 kecelakaan lalu lintas sedangkan di tahun 2018 terjadi 103.672 kecelakaan.

Demi meningkatkan keselamatan jalan, maka harus menemukan dan memperbaiki masalah yang menjadi penyebab kecelakaan jalan, supaya tidak terjadi kecelakaan yang berulang pada tempat dan waktu yang sama pada suatu ruas jalan. Maka sangat dibutuhkan Audit Keselamatan Jalan (AKJ) sebagai suatu sistem yang mengontrol kualitas jalan maupun layanan jalan yang diberikan pada pengguna jalan. AKJ juga dapat dijadikan pemetaan potensi ketidaksesuaian yang dapat menyebabkan terjadinya kecelakaan (Suwarto dan Nugroho, 2019). AKJ wajib dilaksanakan dalam rangka mengurangi angka kematian setiap tahunnya akibat kecelakaan yang fatal. AKJ merupakan cara agar dapat mencegah terjadinya kecelakaan lalu lintas yang pada umumnya terjadi akibat faktor manusia, kondisi jalan, kondisi kendaraan, cuaca, maupun pandangan terhalang hazard (Mahardika, dkk, 2015).

Dari permasalahan kemacetan yang mengakibatkan kecelakaan dengan fatalitas yang tinggi, maka penelitian ini adalah pelaksanakan AKJ dengan metode observasi terhadap 2 ruas jalan yaitu Tol Kunciran-Serpong dan Layang Jakarta-Cikampek II dengan menggunakan formulir Audit Keselamatan Jalan Tahap Operasional yang berjudul: "Audit Keselamatan Jalan Untuk Jalan Tol yang Operasional di Bawah 1 Tahun". Jalan Tol Kunciran-Serpong dan Tol Layang JakartaCikampek II, termasuk jalan tol yang baru saja beroperasi, sehingga penelitian ini tidak mempunyai data kecelakaan lalu lintas dan untuk penelitian ini tidak bisa menggunakan kuisoner dikarenakan jalan tol yang masih baru dan jumlah kendaraan yang melewati masih sedikit. Untuk melakukan AKJ tidak harus berdasarkan data kecelakaan saja, hal ini disebabkan tujuan AKJ adalah untuk dapat menghindari terjadinya kecelakaan dan untuk mengantisipasi kecelakaan yang kemungkinan akan terjadi pada suatu titik, karena jalan yang aman dan nyaman merupakan hal yang sangat penting bagi pengendara dan pengguna jalan (Madeline, 2019).

\section{METODE PENELITIAN}

Metode yang digunakan dalam penelitian ini adalah:

a. Studi literatur dengan berbagai macam sumber, seperti peraturan dan perundangan, jurnal ilmiah, buku, artikel yang berhubungan dengan penulisan ini.

b. Metode survei dengan observasi langsung terhadap Jalan Tol Kunciran-Serpong dan Layang Jakarta-Cikampek II, untuk mengetahui kondisi eksisting dengan menggunakan formulir Audit Keselamatan Jalan Tol.

c. Observasi langsung dengan mempergunakan kamera Go Pro, untuk mengetahui kondisi lingkungan dari Jalan Tol Kunciran-Serpong dan Layang Jakarta-Cikampek II

Tahapan penelitian ini berguna untuk menjadi panduan di dalam pelaksanaan agar penelitian dapat terlaksana dan tidak menyimpang dari tahapan yang di desain sebagai berikut:

a. Tahap persiapan, dengan mempelajari studi literatur, permasalahan yang ada, menetapkan topik penelitian dan lokasi penelitian. 
b. Mengumpulkan data sekunder yang diperlukan sebagai data penunjang yang berupa peraturan dan standar - standar yang berlaku.

c. Melaksanakan observasi langsung di lapangan terhadap geometrik, perkerasan, kecepatan, bangunan pelengkap jalan dan perlengkapan jalan (rambu serta marka).

d. Mengkompilasi data dan melaksanakan analisis serta pembahasan terhadap data yang diperoleh kemudian melakukan perbandingan terhadap standar dari peraturan

e. Menarik kesimpulan dari pembahasan yang telah dilaksanakan.

\section{Metode pengumpulan data}

Pengumpulan data dilakukan dengan survei observasi langsung di jalan Tol Kunciran-Serpong dan Tol Layang Jakarta-Cikampek II dengan menggunakan formulir Audit Keselamatan Jalan. Untuk melakukan metode ini, peneliti akan menggunakan bantuan kamera. Hasil survei yang diperoleh akan dianalisis secara kualitatif untuk mengidentifikasi kriteria dan standar keselamatan yang terdapat di Formulir Audit Keselamatan Jalan terhadap kondisi eksisting jalan Tol Kunciran - Serpong dan Layang Jakarta-Cikampek II.

\section{HASIL DAN PEMBAHASAN}

\section{Kecepatan kendaraan}

Survei kondisi eksisting jalan Tol Kunciran-Serpong dan Tol Layang Jakarta-Cikampek II juga melakukan uji terhadap kecepatan kendaraan, dengan menggunakan peralatan Speed Gun, dimana kecepatan kendaraan eksisting terendah diperoleh $70 \mathrm{~km} / \mathrm{jam}$, tertinggi $120 \mathrm{~km} / \mathrm{jam}$ dan kecepatan rata -rata kendaraan yang melintas di jalan tol Kunciran-Serpong adalah 102,5 km/jam, yang teridentifikasi melebihi kecepatan recana yaitu $100 \mathrm{~km} / \mathrm{jam}$. Hal ini berarti pengemudi tidak mematuhi peraturan, sehingga diperlukan untuk menambah atau memperbanyak rambu peringatan batas kecepatan maksimum dan tindakan yang tegas dari petugas tol yang berwenang. Dapat pula dilakukan pemantauan dengan kamera CCTV dan diberlakukannya hukuman kedisiplinan untuk tidak lagi melewati batas kecepatan maksimum yang dapat menyebabkan kecelakaan dan membahayakan jiwa. Hal yang sama terjadi untuk kecepatan kendaraan yang melewati Tol Layang Jakarta-Cikampek II, diperoleh kecepatan terendah 80km/jam, tertinggi $120 \mathrm{~km} / \mathrm{jam}$, dan rata-rata sebesar 101,5 km/jam. Perlakuan yang sama dengan ruas Tol Kunciran - Serpong juga harus diterapkan di ruas Tol Layang Jakarta-Cikampek II

\section{Ukuran rambu lalu lintas}

Setelah dilakukan pengukuran pada Tol Kunciran-Serpong didapatkan tinggi rambu 2,5m dan pada Tol Layang Jakarta-Cikampek II didapatkan tinggi rambu 2,5 m. Data tersebut memenuhi Peraturan Menteri Perhubungan Republik Indonesia Nomor 13 tahun 2014 tentang rambu lalu lintas pasal 36 ayat 1 dimana tercantum bahwa tinggi rambu minimum $1,75 \mathrm{~m}$ dan paling tinggi 2,65 m. Pengukuran tinggi rambu lalu lintas diukur dari permukaan jalan tertinggi sampai dengan sisi daun rambu bagian bawah.

\section{Spesifikasi jalan tol kunciran-serpong dan tol layang Jakarta-cikampek II}

Setelah dilakukan pengukuran maka diperoleh jalan tol Kunciran-Serpong memiliki lebar jalur 3,6 $\mathrm{m}$ dengan 3 buah lajur, lebar bahu luar $3 \mathrm{~m}$ dan lebar bahu dalam 1,5 m. Memiliki satu buah simpang susun, dan dua persimpangan atau junction. Pada jalan tol layang Jakarta-Cikampek II diperoleh hasil pengukuran lebar lajur 3,5 m dengan 2 buah lajur, lebar bahu luar 2,5 $\mathrm{m}$ dan lebar 
bahu dalam $1 \mathrm{~m}$. Data-data yang sudah diperoleh sesuai dengan Peraturan Menteri Pekerjaan Umum No. 19/PRT/M/2011 tentang persyaratan teknis jalan dan kriteria perencanaan teknis jalan dan juga Geometrik Jalan Bebas Hambatan (2009).

\section{Jarak pandang henti}

Jarak pandang henti berfungsi untuk menghindari terjadinya tabrakan yang dapat membahayakan kendaraan dan manusia dan digunakan sebagai standar untuk menetapkan jarak pandangan minimal terhadap pengemudi untuk dapat berhenti dengan aman sebelum memasuki daerah yang berbahaya. Kecepatan rencana yang didesain pada jalan tol Kunciran-Serpong adalah 100 km/jam dan tol layang Jakarta-Cikampek II adalah $60-80 \mathrm{~km} / \mathrm{jam}$

Departemen Pekerjaan Umum (2009), jarak pandang henti (Ss) dapat dihitung dengan rumus berikut:

$\mathrm{Ss}=0,278 \times \operatorname{Vr} \times \mathrm{T}+\left(0,039 \times \frac{\mathrm{Vr}^{2}}{\mathrm{a}}\right)$

Keterangan:

Ss $\quad=$ jarak pandang henti

$\mathrm{Vr} \quad=$ kecepatan rencana $(\mathrm{km} / \mathrm{jam})$

$\mathrm{T} \quad=$ waktu reaksi, ditetapkan 2,5 detik

A = tingkat perlambatan $\left(\mathrm{m} / \operatorname{detik}^{2}\right)$, ditetapkan 3,4 meter $/$ detik $^{2}$

Sehingga, diperoleh jarak pandang minimum dengan kecepatan $100 \mathrm{~km} / \mathrm{jam}$ adalah $185 \mathrm{~m}$. Untuk melakukan perbandingan agar lebih akurat maka digunakan tabel dari Departemen Perkerjaan Umum (2009) jarak pandang henti (Ss) minimum, dan hasil perhitungan sesuai dengan tabel yang terdapat pada Departemen Perkerjaan Umum (2009) tentang jarak pandang henti.

\section{Analisis observasi langsung}

Berdasarkan hasil analisis observasi langsung pada jalan Tol Kunciran-Serpong dan Tol Layang Jakarta-Cikampek II yang dilakukan per $1 \mathrm{~km}$ panjang ruas, terdapat beberapa hal yang memenuhi peraturan yang sudah ditetapkan, maka disimpulkan:

\section{A. Tol Kunciran-Serpong}

a. Pada km. 45, km. 46, km. 47, km. 48 dan km. 50 menuju Kunciran beberapa ruas jalan perkerasannya tidak rata karena adanya kerusakan perkerasan dengan jenis alur atau rutting.

b. Pada km. 40 menuju Kunciran beberapa ruas jalan perkerasannya tidak rata karena adanya kerusakan perkerasan jalan jenis retak melintang atau transverse cracking.

c. Pada km. 46 dan km. 48 menuju Kunciran beberapa ruas jalan memiliki median jalan yang kurang baik karena tidak sepenuhnya terdapat pagar pemisah jalur.

d. Pada km. 41 sampai km. 42 menuju Kunciran memiliki risiko tinggi karena tidak memiliki peringatan rambu tikungan ke kanan, dan terdapat genangan air pada permukaan jalan

e. Pada km. 42 dan km. 43 menuju Serpong dan km. 43 dan km. 49 menuju Kunciran beberapa ruas jalan perkerasannya tidak rata karena sambungan perkerasan yang kurang baik.

f. Pada km. 40, km. 41, km. 43 dan km. 44 menuju Serpong dan km. 42 menuju Kunciran ruas jalan perkerasannya tidak rata karena adanya kerusakan jenis retak memanjang 
g. Pada km. 48 menuju Serpong dan km. 41, km. 45, km. 47, km. 48 dan km. 49 menuju Serpong ruas jalan tidak memiliki rambu peringatan tikungan baik ke kiri maupun ke kanan.

h. Pada km. 47, km. 48 menuju Serpong dan km. 41 menuju Kunciran terdapat genangan air pada permukaan jalan dan perkerasaan yang tidak rata, berarti jalan ini memiliki sistem drainase yang kurang baik.

\section{B. Tol Layang Jakarta-Cikampek II}

a. Pada km. 13 - km. 14 dari arah Cikunir Bekasi menuju Karawang terdapat beberapa rambu lalulintas yang tidak sesuai dengan geometrik jalan. Geometrik eksisting dari ruas jalan adalah lurus sedangkan rambu yang terpasang adalah rambu peringatan berbelok kekiri.

b. Pada km. 23 - km. 22 dari arah Karawang menuju Cikunir Bekasi terdapat beberapa rambu yang tidak sesuai dengan dengan geometrik jalan. Geometrik eksisting dari ruas jalan adalah berbelok kanan sedangkan rambu yang terpasang memberikan peringatan belokan ganda dengan belokan pertama adalah ke kiri.

c. Pada km. 11 - km. 10 dari arah Karawang menuju Cikunir Bekasi tidak terlihat adanya rambu yang mengarahkan untuk belok. Padahal geometrik jalan eksisting dari ruas jalan adalah belok ke kanan.

\section{Hasil audit dan pembahasan}

Hasil AKJ Tol Kunciran-Serpong hasil observasi dengan berpedoman kepada peraturan, literatur, dan undang-undang yang berlaku dicantumkan Tabel 1 dan Tabel 2.

Tabel 1. Hasil audit keselamatan jalan tol Kunciran-Serpong

\begin{tabular}{|c|c|c|c|}
\hline No. & Masalah Keselamatan & Risiko & Rekomendasi \\
\hline 1. & $\begin{array}{l}\text { Pada km. } 45,46,47,48 \text { dan km. } 50 \text { menuju } \\
\text { Kunciran jalan yang tidak rata karena adanya } \\
\text { kerusakan perkerasan jenis alur atau rutting }\end{array}$ & rendah & $\begin{array}{l}\text { Diusulkan untuk memperbaiki perkerasan } \\
\text { pada daerah yang mengalami kerusakan }\end{array}$ \\
\hline 2. & $\begin{array}{l}\text { Pada km. } 42 \text { dan km. } 43 \text { menuju Serpong dan } \\
\mathrm{km} .43 \text { dan km. } 49 \text { jalan yang tidak rata } \\
\text { karena adanya sambungan antar perkerasan }\end{array}$ & rendah & $\begin{array}{l}\text { Diusulkan untuk memperbaiki perkerasan } \\
\text { pada daerah yang mengalami kerusakan }\end{array}$ \\
\hline 3. & $\begin{array}{l}\text { Pada km. } 40, \mathrm{~km} .41, \mathrm{~km} .43 \text { dan } \mathrm{km} .44 \\
\text { menuju Serpong dan km. } 42 \text { menuju } \\
\text { Kunciran jalan yang tidak rata ada kerusakan } \\
\text { retak memanjang atau longitudinal cracking }\end{array}$ & rendah & $\begin{array}{l}\text { Diusulkan untuk memperbaiki perkerasan } \\
\text { pada daerah yang mengalami kerusakan }\end{array}$ \\
\hline 4. & $\begin{array}{l}\text { Pada km. } 40 \text { menuju Kunciran Jalan yang } \\
\text { tidak rata karena adanya kerusakan melintang } \\
\text { atau transverse cracking }\end{array}$ & rendah & $\begin{array}{l}\text { Diusulkan untuk memperbaiki perkerasan } \\
\text { pada daerah yang mengalami kerusakan }\end{array}$ \\
\hline 5. & $\begin{array}{l}\text { km. } 46 \text { dan km. } 48 \text { menuju Kunciran median } \\
\text { jalan yang tidak sepenuhnya berpagar }\end{array}$ & rendah & $\begin{array}{l}\text { Diusulkan untuk memasang median jalan } \\
\text { pada daerah yang belum mengalami } \\
\text { pemagaran }\end{array}$ \\
\hline 6. & $\begin{array}{l}\text { Pada km. } 48 \text { menuju Serpong dan km. } 41 \text {, } \\
\text { km. } 45, \mathrm{~km} .47, \mathrm{~km} .48 \text { dan km. } 49 \text { tidak } \\
\text { memiliki rambu peringatan tikungan ke kiri } \\
\text { atau ke kanan }\end{array}$ & rendah & $\begin{array}{l}\text { Diusulkan untuk membuat rambu peringatan } \\
\text { tikungan ke kiri atau ke kanan sesuai dengan } \\
\text { geometrik pada ruas jalan yang dibutuhkan }\end{array}$ \\
\hline
\end{tabular}




\begin{tabular}{|c|c|c|c|}
\hline 7. & $\begin{array}{l}\text { Di ruas jalan km. } 47, \mathrm{~km} .48 \text { menuju Serpong } \\
\text { dan } \mathrm{km} .41 \text { menuju Kunciran yang terdapat } \\
\text { genangan air dan perkerasaan yang tidak rata }\end{array}$ & sedang & $\begin{array}{l}\text { Diusulkan untuk memperbaiki perkerasan } \\
\text { pada daerah yang mengalami kerusakan dan } \\
\text { memperbaiki sistem drainase pada ruas } \\
\text { tersebut }\end{array}$ \\
\hline 8. & $\begin{array}{l}\text { Pada km. } 47, \mathrm{~km} .48 \text { menuju Serpong dan } \\
\mathrm{km} .41 \text { menuju Kunciran tidak memiliki } \\
\text { rambu peringatan tikungan ke kiri, genangan } \\
\text { air dan perkerasaan yang tidak rata retak } \\
\text { buaya }\end{array}$ & tinggi & $\begin{array}{l}\text { Diusulkan untuk memperbaiki perkerasan } \\
\text { pada daerah yang mengalami kerusakan, } \\
\text { mempembaiki sistem drainase pada ruas } \\
\text { tersebut dan memberikan rambu peringatan } \\
\text { tikungan ke kiri }\end{array}$ \\
\hline 9. & $\begin{array}{l}\text { Pada ruas jalan km. } 42 \text { menuju Serpong } \\
\text { kerusakan perkerasan jenis alur atau rutting, } \\
\text { tidak memiliki peringatan rambu tikungan ke } \\
\text { kanan, dan pada beberapa daerah tidak } \\
\text { memiliki median jalan }\end{array}$ & tinggi & $\begin{array}{l}\text { Diusulkan untuk memperbaiki perkerasan } \\
\text { pada daerah yang mengalami kerusakan, } \\
\text { memberikan rambu peringatan tikungan ke } \\
\text { kanan, dan memasang median jalan pada } \\
\text { daerah yang belum mengalami pemagaran }\end{array}$ \\
\hline
\end{tabular}

Tabel 2. Hasil audit keselamatan jalan tol layang Jakarta-Cikampek II
No.

\section{Rekomendasi Perbaikan}

\begin{tabular}{|c|c|c|c|}
\hline 1. & $\begin{array}{l}\text { Jalan tidak rata yang disebabkan oleh } \\
\text { sambungan. }\end{array}$ & Rendah & Perlu dilakukan perataan pada sambungan \\
\hline 2. & $\begin{array}{l}\text { Pada } \mathrm{Km} 11-\mathrm{Km} 10 \text { dari arah } \\
\text { Karawang menuju Cikunir, tidak } \\
\text { terdapat rambu peringatan tikungan ke } \\
\text { kanan. }\end{array}$ & Sedang & $\begin{array}{l}\text { Diusulkan untuk dilakukan pemasangan } \\
\text { rambu peringatan di ruas jalan tersebut. }\end{array}$ \\
\hline 3. & $\begin{array}{l}\text { Pada km. } 13-\mathrm{km} .14 \text { dari arah Cikunir } \\
\text { menuju Karawang terdapat rambu yang } \\
\text { tidak sesuai, terpasang rambu peringatan } \\
\text { tikungan ke kiri sedangkan jalan lurus. }\end{array}$ & Tinggi & $\begin{array}{l}\text { Diusulkan untuk melepas rambu karena tidak } \\
\text { sesuai dengan geometrik di ruas jalan tersebut. }\end{array}$ \\
\hline 4. & $\begin{array}{l}\text { Pada km. } 23-\mathrm{km} .22 \text { dari arah Karawang } \\
\text { menuju Cikunir, terdapat rambu yang } \\
\text { tidak sesuai, terpasang rambu peringatan } \\
\text { tikungan ganda dengan tikungan pertam } \\
\text { ke kiri, tetapi rambu tersebut menikung } \\
\text { ke kanan. }\end{array}$ & Tinggi & $\begin{array}{l}\text { Diusulkan untuk mengganti rambu yang } \\
\text { terpasang dan disesuaikan denga geometrik di } \\
\text { ruas jalan tersebut. }\end{array}$ \\
\hline
\end{tabular}

\section{KESIMPULAN DAN SARAN}

\section{Kesimpulan}

Berdasarkan analisis data penelitian yang telah dilakukan, kesimpulan yang didapat berdasarkan hasil pengamatan langsung:

\section{A. Tol Kunciran-Serpong}

a. Kondisi perkerasan jalan terdapat beberapa jenis kerusakan yang mengakibatkan ketidaknyamanan sampai timbulnya kecelakaan bagi pengguna jalan, apabila dalam kecepatan tinggi kerusakan perkerasan akan mengakibatkan kecelakaan yang lebih fatal

b. Median jalan sudah cukup baik dan membatasi dua aliran lalu lintas yang berlawanan arah sehingga tidak ada kendaraan yang memutar balik namun pada beberapa ruas jalan masih ada yang tidak diberikan pemagaran. Peraturan Pemerintah Republik Indonesia Nomor 15 Tahun 2005 tentang jalan tol bahwa semua ruas jalan tol harus dilakukan pemagaran.

c. Rambu lalu lintas masih banyak yang kurang misalnya km. 48 menuju Serpong dan km. $41, \mathrm{~km} .45, \mathrm{~km} .47, \mathrm{~km} .48$ dan km. 49 tidak memiliki rambu peringatan tikungan ke kiri 
atau ke kanan. Kekurangan rambu apalagi rambu peringatan berbelok akan menyebabkan kurangnya antisipasi pengemudi terhadap situasi geometric berbelok,yang apabila dalam kecepatan tinggi dapat menyebabkan kecelakaan fatal

d. Marka jalan dalam kondisi yang baik, marka jalan dapat dilihat dengan jelas, warna garis marka, penempatan dan fungsi marka sesuai standar

e. Pengukuran kecepatan kendaraan dengan menggunakan speed gun diperoleh kecepatan rata-rata yaitu $102,5 \mathrm{~km} / \mathrm{jam}$, melebihi kecepatan rencana $80-100 \mathrm{~km} / \mathrm{jam}$

\section{B. Tol Layang Jakarta-Cikampek II}

a. Perkerasan cukup baik tidak terdapat retakan, lubang, tetapi jalan bergelombang akibat sambungan

b. Geometrik dalam kondisi baik, rambu yang terpasang sudah sesuai dengan kecepatan rencana 60 - $80 \mathrm{~km} / \mathrm{jam}$, walaupun data hasil survei kecepatan eksisting $85 \mathrm{~km} / \mathrm{jam}$ sampai dengan $120 \mathrm{~km} / \mathrm{jam}$. Sehingga kemungkinan terdapat (spot) jalan yang tidak memenuhi syarat jarak pandang henti, jadi perlu ditambahkan lebih banyak rambu pembatas kecepatan dan dilakukan pengecekan kecepatan kendaraan yang melintas secara berkala. Perlu ditambahkan juga pantauan CCTVuntuk mengawasi kecepatan kendaraan.

c. Marka dalam kondisi sangat baik, dapat dilihat dengan jelas, warna garis marka, penempatan dan fungsi sudah sesuai standar

d. Median melalui pengukuran tinggi 1,2 meter median dalam kondisi baik

e. Ditemukan rambu yang tidak sesuai di km. 13 - km. 14 dari arah Cikunir Bekasi ke Karawang Jawa Barat, dimana jalan lurus sedangkan rambu peringatan yang terpasang tikungan ke kiri. Pada km. 23 - km. 22 dari arah Karawang Jawa Barat ke Cikunir Bekasi juga terdapat rambu yang tidak sesuai, dimana jalan menikung ke kanan dan rambu yang terpasang sebelum tikungan rambu peringatan tikungan ganda dengan tikungan pertama ke kiri. Pada km. 11 - km. 10 dari arah Karawang Jawa Barat ke Cikunir Bekasi tidak terdapat rambu lalu lintas yang mengarahkan tikungan.

f. Ukuran rambu, terpasang tinggi 2,25meter sudah memenuhi standar, untuk daun rambu yang terpasang 0,6 x 0,7meter (sedang) tidak sesuai dengan Peraturan Menteri Perhubungan Republik Indonesia Nomor 13 tahun 2014 tentang rambu lalu lintas pasal 37 ayat 3.

g. Ukuran lebar ruas jalan, 2 lajur dengan lebar lajur 3,5 meter, lebar bahu luar 2,5meter dan lebar bahu dalam 1 meter, sudah memenuhi syarat Geometrik Jalan Bebas Hambatan.

\section{Saran}

Setelah penelitian ini selesai dibuat, penulis ingin memberikan saran untuk penelitian lebih lanjut, yaitu dengan melakukan pengecekan ulang terhadap video rekaman untuk memastikan tidak ada yang kurang dan terlewatkan.

\section{REFERENSI}

Indikator Kecelakaan Lalu Lintas di Jalan Tol Menurut Ruas Jalan. (2018). Dipetik Februari 28, 2020, dari Badan Pusat Statistik Provinsi DKI Jakarta:

https://jakarta.bps.go.id/dynamictable/2020/01/20/155/9-1-19-indikator-kecelakaan-lalulintas-di-jalan-tol-menurut-ruas-jalan.html

Madeline, S. J. (2019). Audit Keselamatan Jalan Tol Palimanan-Pejagan. 
Mahardika, A., Widodo, W., \& Widianti, A. (2015). Audit Keselamatan Jalan Simpang Kronggahan-Simpag Monjali.

Mulyono, A. T., Kushari, B., \& Gunawan, H. E. (2009). Audit Keselamatan Infrastruktur Jalan (Studi Kasus Jalan Nasional KM 78-KM 79 Jalur Pantura Jawa, Kabupaten Batang). Jurnal Teoritis dan Terapan Bidang Rekayasa Teknik Sipil.

Mustikarani, W., \& Suherdiyanto. (2016). Analisis Faktor-Faktor Penyebab Kemacetan Lalu Lintas Di Sepanjang Jalan H Raisa Rahman (Sui Jawi) Kota Pontianak.

Organization, W. H. (2018). Global status report on road safety 2018. France: World Health Organization.

Peraturan Menteri Perhubungan Republik Indonesia Nomor PM 13 Tahun 2014 tentang Rambu Lalu Lintas. (2014). Menteri Perhubungan Republik Indonesia. (2005). Peraturan Pemerintah Republik Indonesia Nomor 15 Tahun 2005 tentang Jalan Tol.

Puslitbang. (2013, Maret 4). Diambil kembali dari www.dephub.go.id

Sediono, W., \& Handoko, D. (2004). Pemodelan dan Simulasi Antrian Kendaraan di Gerbang Tol.

Setiawan, D., \& Asima, M. (2019). Pemetaan Risiko Kecelakaan Lalu Lintas di Ruas Jalan Tol Cipularang. Jurnal Teknik Sipil.

Setyarini, N. (2019). Persepsi Pengemudi Terhadap Bangunan Pelengkap Jalan Di Tol Cipularang. Jurnal Bakti Masyarakat Indonesia.

Standar Konstruksi dan Bangunan tentang Geometri Jalan Bebas Hambatan untuk Jalan Tol. (2009). Departemen Pekerjaan Umum Direktorat Jenderal Bina Marga.

Suwarto, F., \& Nugroho, A. (2019). Audit Keselamatan Jalan sebagai Dasar Implementasi Perencanaan Karakteristik Jalan. Jurnal Proyek Teknik SIpil.

Wijnen, W., \& Stipdonk, H. (2016). Social costs of road crashes: An international analysis. Accident Analysis and Prevention, 97-106.

Zanuardi, A., \& Suprayitno, H. (2018). Analisa Karakteristik Kecelakaan Lalu Lintas di Jalan Ahmad Yani Surabaya melalui Pendekatan Knowledge Discovery in Database. Jurnal Manajemen Aset Infrastruktur dan Fasilitas. 